\title{
Importance of blood cellular genomic profile in coronary heart disease
}

\author{
M. Iqbal Baba ${ }^{1}$, Deepak Kaul ${ }^{1, *} \&$ Anil Grover ${ }^{2}$ \\ ${ }^{1}$ Department of Experimental Medicine \& Biotechnology, Post Graduate Institute of Medical Education and \\ Research, Chandigarh, 160012, India; ${ }^{2}$ Department of Cardiology, Post Graduate Institute of Medical \\ Education and Research, Chandigarh, 160012, India
}

Received 13 March 2005; accepted 30 September 2005

(C) 2005 National Science Council, Taipei

Key words: blood, coronary heart disease, cellular genomics, interrelationship, lipid

\begin{abstract}
Summary
Since receptor/transcription factor family especially peroxisome proliferator-activated receptors PPARs $(\alpha, \gamma)$ and liver X receptor $\alpha(\mathrm{LXR} \alpha)$ have been recognized to play crucial role in both lipid metabolism and inflammation, the present study was addressed to explore the interrelationship between blood cellular genomic expression profile, serum lipid levels and severity of coronary heart disease (CHD) in human subjects. Based upon the demographic and laboratory data, the human subjects were divided into 4 groups. Genomic expression profile in the subjects belonging to these groups was determined by measuring the transcriptional expression of genes coding for PPARs $(\alpha, \gamma)$, CD36, LXR $\alpha$ and low density lipoprotein receptor (LDLR) in their blood mononuclear cells. This genomic expression profile was correlated with serum lipid profile as well as with the severity of CHD (revealed by coronary angiography coupled with modified Gensini score) using standard statistical analytical methods. Further in vitro and in vivo effect of statins on such genomic profile was also explored. Although genes coding for PPARs $(\alpha, \gamma)$, CD36, LDLR showed correlation with the severity of coronary atherosclerosis, blood cellular LXR $\alpha$ genomic profile showed conspicuous negative correlation with the severity of coronary atherosclerosis in subjects with or without hypercholesterolemia. This view was further confirmed in experiments directed to understand the effect of statins on the cellular genomic profile of PPARs $(\alpha, \gamma)$ and LXR $\alpha$. Based on these reported findings, we propose that blood cellular LXR $\alpha$ genomic profile has a protective effect against the development of CHD and hence may be of importance in devising synthetic therapeutic drugs for CHD in future.
\end{abstract}

\section{Introduction}

Atherosclerosis, the underlying cause behind the occurrence of cardiovascular and cerebrovascular diseases, is still leading cause of morbidity and mortality in the developed countries, inspite of improved pharmacological and other dietary approaches [1]. Oxidative modification of low-density lipoprotein (LDL) and "vascular inflammatory process" are the two fundamental mechanisms, recognized widely to be involved in atherogenesis. In fact, cooperativity between oxidation and

*To whom correspondence should be addressed. Fax +910172-2744401; E-mail: dkaul_24@hotmail.com inflammation seems to be the key event in the development of early atherosclerotic lesions [2].

Peroxisome proliferator-activated receptors (PPARs) are a group of nuclear receptors which have the inherent ability to regulate genes involved in lipid peroxidation as well as inflammatory process [3-5]. These nuclear receptors regulate the expression of many genes involved in the production of proinflammatory cytokines, adhesion molecules and receptors (CD36, SR-A, SR-B1) that control the native and oxidized LDL (oxLDL) uptake [5-7]. All these effector genes are involved in the initiation of atherosclerotic lesions including monocyte recruitment into the vessel wall. It is natural that PPARs have been shown to be 
involved in various diseases such as dyslipidemia, obesity, diabetes, atherosclerosis and cancer [8].

Liver X receptor $(\operatorname{LXR} \alpha)$ also belongs to nuclear receptor family, regulates genes coding for Apo-E, ATP binding cassette A1 (ABCAI) cholesterol transporter, sterol regulatory element binding protein (SREBP) and IL-8 which play crucial role in atherosclerosis [9-11]. Uptake of oxLDL uptake through CD36 provides the ligands not only for PPARs $(\alpha, \gamma)$ but also for $\operatorname{LXR} \alpha$ [12]. PPAR $\gamma$ upregulates CD36 and downregulates LDL receptor (LDLR) gene transcription [13] and initiates a vicious cycle leading to foam cell formation [14]. Thus it is reasonable to assume that PPARs $(\alpha, \gamma)$ and their effector genes such as $\mathrm{LXR} \alpha, \mathrm{CD} 36$ and LDLR have the inherent ability to initiate a cross-talk between vascular lipid peroxidation and inflammation leading to early development of atherosclerotic lesions. It is in this context the present study was addressed to explore the interrelationship between transcriptional expression of these genes, lipid profile and severity of coronary heart disease (CHD).

\section{Materials and methods}

\section{Selection criteria and design}

Based upon the demographic and laboratory data including age, sex, traditional risk factors, lipidogram, family history of CHD and angiographic findings, a total of untreated 64 male subjects (3475 years) with their prior informed consent were assigned to the following main four groups:

Group I Normocholesterolemic with CHD

Group II Normocholesterolemic without CHD

Group III Hypercholesterolemic with CHD

Group IV Hypercholesterolemic without CHD

The division of subjects into above-mentioned four groups was done keeping in mind the controversial role of cholesterol in the genesis of CHD. Group II is meant to serve as a meaningful control because the subjects belonging to this group will have normal cholesterol levels without CHD and hence can serve as a control group against Group I (containing subjects having normal cholesterol levels with CHD). Similarly Group IV having subjects with hypercholesterolemia coupled with no CHD can serve as a control against Group III (containing subjects with hypercholesterolemia coupled with CHD). Criteria for CHD were: myocardial infarction (chest pain associated with electrocardiographic (ECG) evidence of myocardial infarction or raised cardiac enzymes or both); unstable angina (cardiac pain associated with dynamic ECG abnormalities); angiographically proven coronary artery disease ( $>50 \%$ stenosis in one or more major epicardial vessel in multiple projections). Exclusion criteria for both patients and controls included cardiomyopathy, serious organ disease, systemic illness, chronic alcohol abuse, serious psychiatric illness, anticonvulsant therapy, and, for controls, the presence of pathological Q waves on the ECG. The study was approved by our institute research ethics committee and all individuals gave written informed consent. The investigation conformed with the principles outlined in the Declaration of Helsinki (Cardiovascular research1997; 35: pp. 2$4)$.

\section{Serum lipid profile}

Lipidogram, comprising of total cholesterol, total triglycerides, high-density lipoprotein (HDL) cholesterol and low-density lipoprotein (LDL) cholesterol of each human subject was elucidated using standard commercial kits (Randox, United Kingdom). ATP III classification was used for categorization of subjects having either normolipidemic or hyperlipidemic profile [15].

\section{Severity of coronary heart disease}

On the basis of clinical and angiographic findings, the human subjects were categorized to have either CHD or normal coronaries. Coronary angiograms were scored by modified Gensini score [16]. The most severe stenosis in each of the eight coronary segments was graded $1-4(1-1-49 \%$ lumen diameter reduction; 2 - 50-74\% stenosis; 3 - 75$99 \%$ stenosis; $4-100 \%$ occulusion) to give a total score of between 0 and 32. This score therefore was taken to measure both severity and extent of coronary heart disease.

\section{Transcriptional expression of genes}

Mononuclear cells were isolated from human subjects (Groups I-IV) who had been fasting for 
$12 \mathrm{~h}$ before blood donation by employing FicollHypaque density gradient method [17]. These cells were processed for RNA isolation [18] and the integrity of isolated RNA was verified by electrophoresis through denaturing agarose gels stained with ethidium bromide. First strand cDNA was synthesized using random hexamer primers and Moloney murine leukemia virus (M-MuLV) reverse transcriptase in $20 \mu \mathrm{l}$ reaction volume. Reagents were obtained from RevertAid ${ }^{\mathrm{TM}}$ first strand cDNA synthesis kit (Fermentas). cDNA of each sample was amplified by PCR using specific primers for genes coding for PPARs $(\alpha, \gamma)$, LXR $\alpha$, CD36, LDLR and $\beta_{2}$ microglobulin $\left(\beta_{2} M\right)$ [19-21]. $\beta_{2} \mathrm{M}$ amplification was used as a control for RNA loading and efficiency of reverse transcription. PCR reagents were procured from Qiagen and MBI Fermentas. The specific primers were obtained from GENSET Singapore Biotech Pvt Ltd and MWG-Biotech AG. PCR was performed in a $25 \mu 1$ reaction mixture containing $1 \times$ PCR buffer, $2.5 \mathrm{mM} \mathrm{MgCl} 2,0.2 \mathrm{mM}$ of each dNTP, $0.5 \mu \mathrm{M}$ of each primer and 0.625 units of Taq (Thermus aquaticus) and nuclease free water. $1 \mu 1$ of cDNA from cDNA synthesis reaction mixture was used as a template in each PCR. The PCR cycling conditions of these genes were selected such that they were in the linear phase of amplification. Table 1 indicates the number of amplication cycles and the sequence of the primers used. The amplicons were resolved in $2 \%$ agarose gels containing ethidium bromide. The ethidium bromide stained products were photographed and the intensity of bands was analyzed using Scion Image analysis software. The level of mRNA expression of each gene was given by normalizing RT-PCR band intensity of the gene in question to $\beta_{2} \mathrm{M}$ band intensity.

\section{In vitro and in vivo effect of statins}

Mononuclear cells were isolated from normal human subjects having a normal serum lipid profile, who had been fasting for $12 \mathrm{~h}$ and abstained from any medication for two weeks before blood donation, by employing Ficoll-Hypaque density gradient method [17]. These cells were maintained in Dulbecco's modified eagle's medium (DMEM) supplemented with $10 \%$ FCS, $2 \mathrm{mM} \mathrm{L-}$ glutamine, $20 \mathrm{mM}$ sodium bicarbonate, $20 \mathrm{mM}$ HEPES and antibiotics at $37{ }^{\circ} \mathrm{C}$ in a humidified $5 \% \mathrm{CO}_{2}$ incubator. Cells were seeded at $2 \times 10^{5}$ cells/well in 24-well culture plates and subsequently exposed to growth medium without or with mevastatin $(30 \mu \mathrm{M})$ for $24 \mathrm{~h}$ at $37{ }^{\circ} \mathrm{C}$ in $5 \%$ $\mathrm{CO}_{2}$ atmosphere. At the end of the incubation period, these cells together with mononuclear cells (obtained from CHD patients receiving $20 \mathrm{mg}$ of atorvastatin orally daily) were processed for RNA isolation [18] followed by RT-PCR using specific primers for genes coding for PPAR $(\alpha, \gamma), \operatorname{LXR} \alpha$ and $\mathrm{B}_{2} \mathrm{M}$ [19-21]. These culture experiments were done in triplicate to check the reproducibility of the data.

\section{Statistical analysis}

Numerical values for each measurement are shown as mean \pm SEM. Demographic and clinical data of four study groups were analyzed using one-way

Table 1. Characteristics of primers used for RT-PCR.

\begin{tabular}{|c|c|c|c|c|c|}
\hline Gene & GenBank accession number & Primer & Sequence & Fragment length (bp) & PCR cycles \\
\hline \multirow[t]{2}{*}{ LDLR } & NM000527 & Forward & 5'-CAATGTCTCACCAAGCTCTG-3' & 258 & 26 \\
\hline & & Reverse & 5'-TCTGTCTCGAGGGGTAGCTG-3' & & \\
\hline \multirow[t]{2}{*}{$\mathrm{LXR} \alpha$} & NM005693 & Forward & 5'-CAGAGAGGAAGCCAGGATGCC-3' & 564 & 29 \\
\hline & & Reverse & 5'-GAGCGCCGGTTACACTGTTGC-3' & & \\
\hline \multirow[t]{2}{*}{ CD36 } & L06850 & Forward & 5'-GAGAACTGTTATGGGGCTAT-3' & 389 & 26 \\
\hline & & Reverse & 5'-TTCAACTGGAGAGGCAAAGG-3' & & \\
\hline \multirow[t]{2}{*}{$\operatorname{PPAR} \gamma$} & L40904 & Forward & 5'-TCTCTCCGTAATGGAAGACC-3' & 474 & 33 \\
\hline & & Reverse & 5'-GCATTATGAGACATCCCCAC-3' & & \\
\hline \multirow[t]{2}{*}{$\operatorname{PPAR} \alpha$} & NM013196 & Forward & 5'-AGATTTCGCAATCCATCGGC-3' & 276 & 32 \\
\hline & & Reverse & 5'-GCGTGGACTCCGTAATGATA-3' & & \\
\hline \multirow[t]{2}{*}{$\beta_{2} \mathrm{M}$} & NM4048 & Forward & 5'-GAATTGCTATGTGTCTGGGT-3' & 257 & 20 \\
\hline & & Reverse & 5'-САТСТTCAAACСТCCATGATG-3' & & \\
\hline
\end{tabular}


analysis of variance (ANOVA). On observing statistical significance in the components of serum lipids, the multiple comparisons of each of the components amongst various groups were made by post hoc Bonferroni test. For not normally distributed variables, the non-parametric MannWhitney $U$-test was used to analyse the difference between two groups in the transcriptional expression of genes coding for PPAR $\alpha, \operatorname{PPAR} \gamma, \mathrm{CD} 36$, LXR $\alpha$ and LDLR. Levene's test examined homogeneity of variance. Correlation between two variables was evaluated by Spearman rank-correlation coefficients. $P$ values less than 0.05 were taken to be significant. Analyses were performed with the use of SPSS for Windows version 10.0.

\section{Results}

The groups were compared with respect to age, the concentrations of total cholesterol, LDL-cholesterol, HDL-cholesterol and triglycerides, and the transcriptional expression of genes coding for PPAR $\alpha, \operatorname{PPAR} \gamma, \mathrm{CD} 36, \mathrm{LXR} \alpha$ and LDLR. Table 2 represents the demographics and clinical characteristics of study subjects belonging to Groups I-IV. The $p$-value given by ANOVA showed significant differences $(p<0.001)$ in the levels of total cholesterol, LDL-cholesterol, trigly- cerides and HDL-cholesterol $(p=0.05)$ of study subjects belonging to Groups I-IV. Further the post hoc Bonferroni test showed that the level of cholesterol in subjects belonging to Groups III and IV was highly significant $(p<0.001)$ as compared to subjects belonging to Groups I and II respectively. The mean level of LDL-cholesterol was again highly significant $(p<0.001)$ in subjects belonging to Groups III and IV as compared to subjects belonging to Groups I and II. Group III subjects had significant $(p<0.05)$ higher HDLcholesterol levels than Group II subjects. The mean level of triglycerides was significant $(p<0.05)$ in Group III subjects versus Group II subjects and highly significant $(p<0.001)$ when compared to subjects belonging to Group I (Table 2). The transcriptional expression of genes coding for PPAR $\alpha$, PPAR $\gamma, \mathrm{CD} 36, \mathrm{LXR} \alpha$ and LDLR within blood mononuclear cells derived from Group I subjects was significantly higher $(p<0.001)$ than that observed in blood mononuclear cells from subjects of Group II (Figure 1a and b). However expression profile at the transcriptional level within blood mononuclear cells derived from subjects of Groups III and IV revealed significance $(p<0.003)$ only in case of LXR $\alpha$ gene (Figure $1 b$ ).

Further genomic expression of PPAR $\alpha, \operatorname{PPAR} \gamma$, LXR $\alpha$ and LDLR within blood mononuclear cells

Table 2. Demographics and Clinical Characteristics of the 4 Study Groups.

\begin{tabular}{|c|c|c|c|c|c|c|}
\hline & \multicolumn{4}{|l|}{ Groups $^{\#}$} & \multirow[t]{2}{*}{$p$-value (ANOVA) } & \multirow[t]{2}{*}{$p$-value (post hoc tests) } \\
\hline & $\mathrm{I}(\mathrm{n})=21$ & $\mathrm{II}(\mathrm{n})=15$ & $\mathrm{III}(\mathrm{n})=16$ & $\mathrm{IV}(\mathrm{n})=12$ & & \\
\hline Age (years) & $53.7 \pm 2.0$ & $52.0 \pm 2.0$ & $50.4 \pm 1.9$ & $47.7 \pm 1.9$ & NS & - \\
\hline Sex & $\mathrm{M}$ & M & M & M & NA & - \\
\hline $\mathrm{TC}(\mathrm{mg} / \mathrm{dl})$ & $174.6 \pm 7.3$ & $164.6 \pm 9.0$ & $264.7 \pm 5.8^{\mathrm{b}}$ & $263.2 \pm 6.2^{\mathrm{b}}$ & $<0.001$ & $\begin{array}{l}\text { III vs. I } \& \text { II }(p<0.001) \\
\text { IV vs. I } \& \text { II }(p<0.001)\end{array}$ \\
\hline LDL-C (mg/dl) & $104.3 \pm 7.2$ & $98.6 \pm 8.7$ & $157.7 \pm 7.6^{\mathrm{b}}$ & $175.8 \pm 6.2^{\mathrm{b}}$ & $<0.001$ & $\begin{array}{l}\text { III vs. I } \& \text { II }(p<0.001) \\
\text { IV vs. I \& II }(p<0.001)\end{array}$ \\
\hline HDL-C (mg/dl) & $39.9 \pm 1.5$ & $36.1 \pm 2.2$ & $43.6 \pm 1.6^{\mathrm{a}}$ & $41.2 \pm 1.9$ & 0.050 & III vs. II $(p<0.05)$ \\
\hline $\mathrm{TG}(\mathrm{mg} / \mathrm{dl})$ & $156.2 \pm 4.3$ & $175.0 \pm 32.1$ & $282.5 \pm 25.5^{\mathrm{a}, \mathrm{b}}$ & $226.7 \pm 22.0$ & 0.001 & $\begin{array}{l}\text { III vs. II }(p<0.05) \\
\text { III vs. I }(p<0.001)\end{array}$ \\
\hline Glucose (mg/dl) & $101.4 \pm 2.7$ & $87.2 \pm 2.6$ & $100.5 \pm 2.7$ & $90.2 \pm 2.6$ & NS & - \\
\hline *Gensini score & $32.3 \pm 3.3$ & 0.0 & $32.0 \pm 4.0$ & 0.0 & NA & - \\
\hline
\end{tabular}

Abbreviations: ANOVA = analysis of variance; $\mathrm{TC}=$ total cholesterol; $\mathrm{LDL}-\mathrm{C}=$ low-density lipoprotein cholesterol; HDL-C $=$ highdensity lipoprotein cholesterol; $\mathrm{TG}=$ triglycerides; $\mathrm{NS}=$ nonsignificant; $\mathrm{NA}=$ not applicable; $\mathrm{M}=$ male; ${ }^{*}$ Gensini score was calculated as the index of the severity of CHD. " Group I - Normocholesterolemic with CHD; Group II - Normocholesterolemic without CHD; Group III - Hypercholesterolemic with CHD; Group IV - Hypercholesterolemic without CHD; The values are mean \pm SEM. Statistical comparisons among groups were tested by one way ANOVA followed by Bonferroni test. ${ }^{\mathrm{a}} p<0.05$ and ${ }^{\mathrm{b}} p<0.001$ gives statistical significance for comparison. 

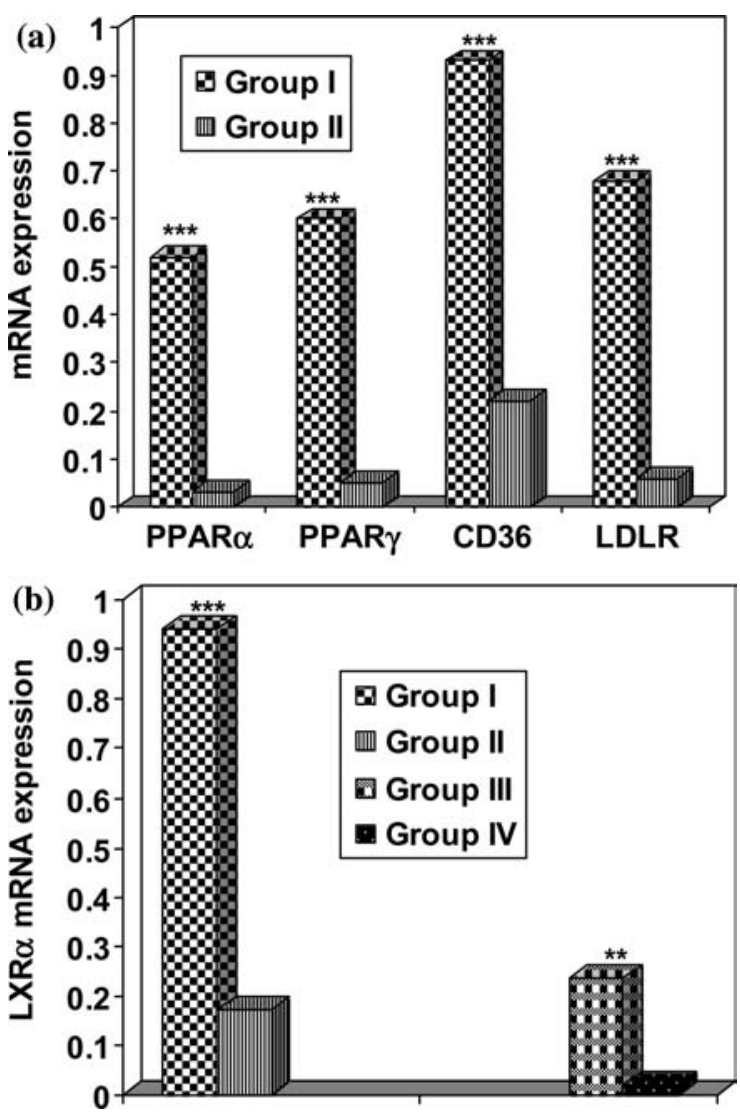

Figure 1. Median of normalized mRNA levels in blood mononuclear cells (a) PPAR $\alpha, \operatorname{PPAR} \gamma, \mathrm{CD} 36$ and LDLR mRNA expression in subjects belonging to Groups I and II. (b) LXR $\alpha$ mRNA expression in subjects belonging to Groups I-IV. Statistically significant difference $(p<0.001)$ is indicated by*** in Groups I and II, and $(p<0.05)$ by** in Groups III and IV.

derived from diseased Groups I and III showed significant correlation with serum lipid profile of subjects belonging to these groups (Figure 2). However, no significant correlation was found between serum total cholesterol $(r=-0.162$, $p=0.337), \quad$ LDL-cholesterol $\quad(r=-0.069$, $p=0.687)$, HDL-cholesterol $(r=-0.098, p=0.563)$ and triglycerides $(r=-0.294, p=0.078)$ with severity of coronary atherosclerosis. At the intergene level LXR $\alpha$ mRNA expression had significant positive correlation with $\operatorname{PPAR} \alpha \quad(r=0.542$, $p=0.001)$ and PPAR $\gamma(r=0.382, p=0.019) \mathrm{mRNA}$ expression. Further highly significant positive correlation was also observed at the intergene level between LDLR and PPAR $\alpha$ mRNA expression $(r=0.474, p=0.003)$ and LDLR and PPAR $\gamma$ mRNA expression $(r=0.412, p=0.011)$.
Significant intergene correlations and correlations between lipid profile and genomic expression have also been observed in control Groups II and IV. Genes coding for PPAR $\gamma$ and LXR $\alpha$ showed significant negative correlations with total cholesterol $(r=-0.542, \quad p=0.004$ and $r=-0.647$, $p=<0.001)$ respectively. Significant intergene correlations were found between mRNA expression of PPAR $\gamma$ and $\operatorname{LXR} \alpha(r=0.484, p=0.011)$ and PPAR $\gamma$ and $\operatorname{LDLR}(r=-0.567, p=0.002)$ respectively. Here in Groups II and IV significant negative correlation was observed between PPAR $\gamma$ and LDLR mRNA expression (Figure 3b) in contrast to Groups I and III (Figure 3a) where positive correlation was observed.

Blood cellular PPAR $\alpha$ mRNA expression in subjects belonging to Group I showed positive correlation with severity of coronary atherosclerosis whereas reverse was true in subjects belonging to Group III (Figure 4a). Although PPAR $\gamma$ did not show any correlation with the severity of coronary atherosclerosis in subjects belonging to Group III, a negative correlation of this gene transcript was observed in subjects belonging to Group I (Figure 4b). Blood cellular CD36 mRNA expression profile showed positive correlation with the severity of coronary atherosclerosis within subjects of Group I whereas no correlative trend was observed in the case of Group III subjects (Figure 4c). Blood cellular LDLR mRNA expression showed negative correlation with the severity of coronary atherosclerosis only in subjects belonging to Group I whereas noticeable trend was not observed in subjects of Group III (Figure 4d). Blood cellular LXR $\alpha$ mRNA expression conspicuously showed negative correlation with the severity of coronary atherosclerosis in subjects belonging to both Groups I and III (Figure 4e).

Experiments directed to understand the effect of statins on the transcriptional expression of genes coding for PPAR $\alpha, \operatorname{PPAR} \gamma$ and $\operatorname{LXR} \alpha$ within normal blood mononuclear cells in vitro culture revealed significant $(p<0.001)$ downregulation of genes coding for PPAR $\alpha$ and PPAR $\gamma$ accompanied by significant $(p<0.001)$ upregulation of LXR $\alpha$ gene (Figure 5a and c). These results were also simulated in blood mononuclear cells derived from CHD patients who were receiving $20 \mathrm{mg}$ of atorvastatin orally daily (Figure 5b and $\mathrm{d}$ ). 

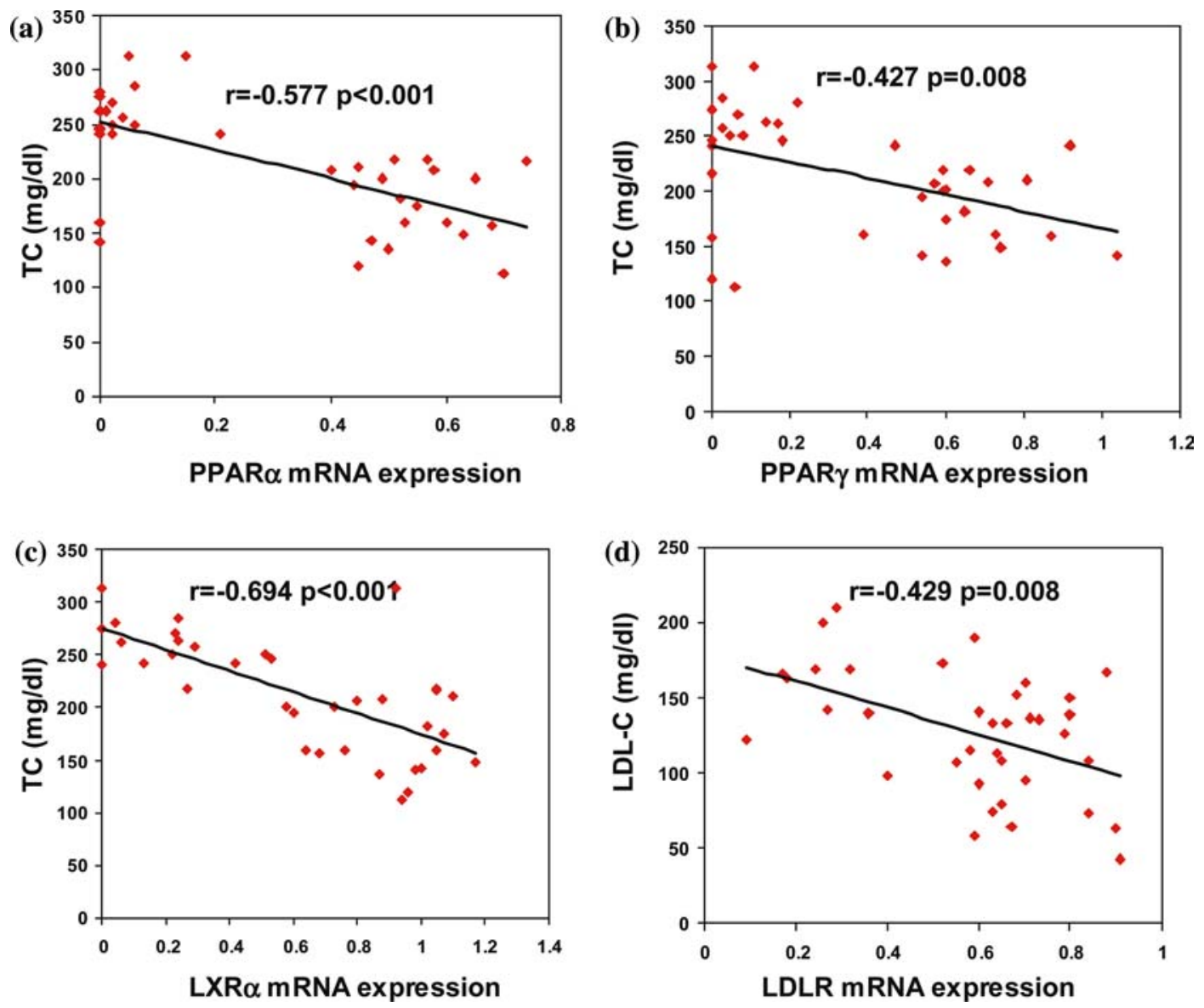

Figure 2. Statistical correlation between the transcriptional expression of genes coding for PPAR $\alpha$, PPAR $\gamma$, LXR $\alpha$ and LDLR, and fasting serum lipid profile [total cholesterol (TC) \& low-density lipoprotein cholesterlol (LDL-C)] in blood mononuclear cells from human subjects belonging to Groups I and III. Values for " $r$ " are Spearman rank correlation coefficients.
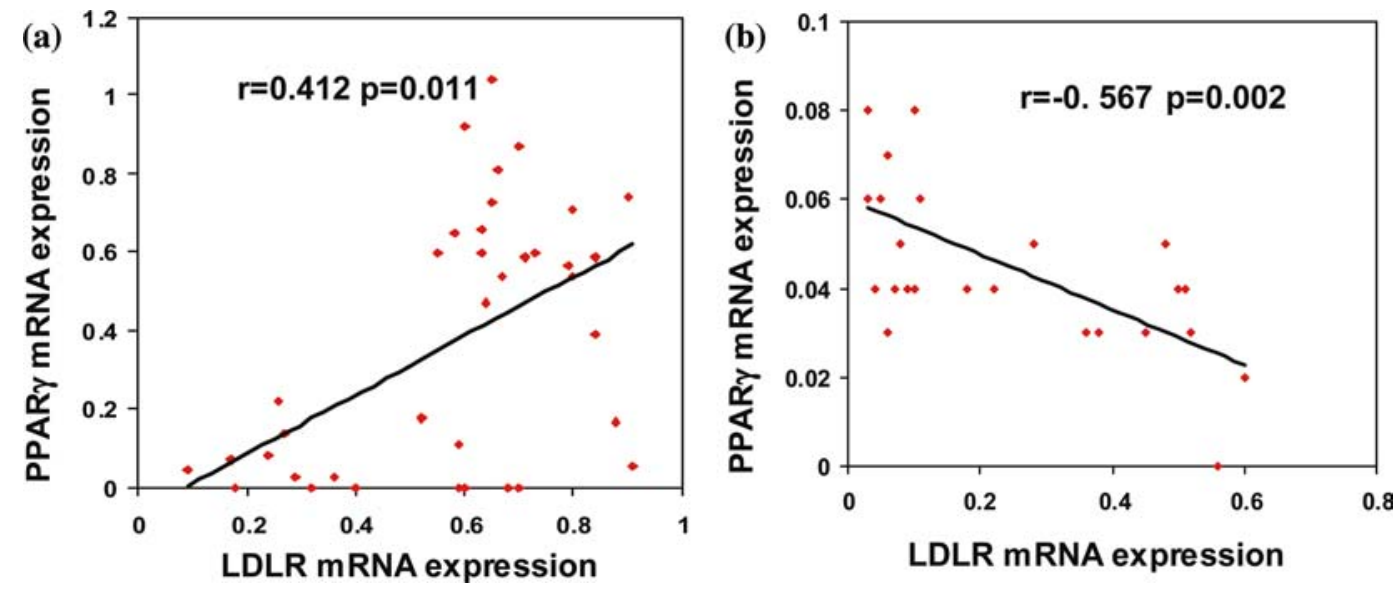

Figure 3. Intergene correlations between PPAR $\gamma$ and LDLR in blood mononuclear cells from human subjects belonging to: (a) Groups I and III. (b) Groups II and IV. Values for " $r$ " are Spearman rank correlation coefficients. 

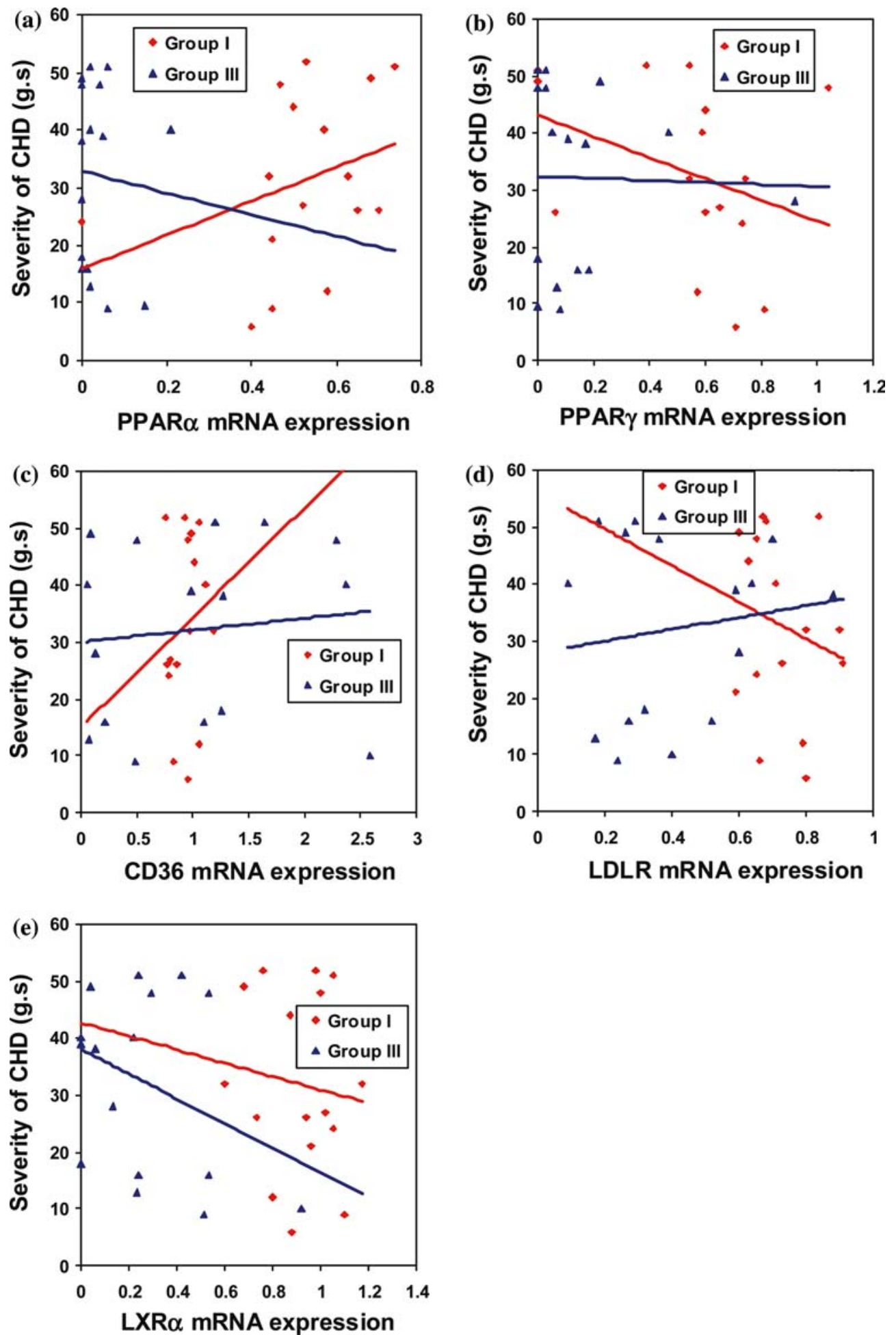

Figure 4. Relationship between severity of coronary heart disease (CHD) and (a) PPAR $\alpha$, (b) PPAR $\gamma$, (c) CD36 (d) LDLR and (e) LXR $\alpha$ mRNA levels within blood mononuclear cells in CHD patients belonging to Groups I and III. Gensini score (g.s) was calculated as the index of the severity of CHD. 
(a)
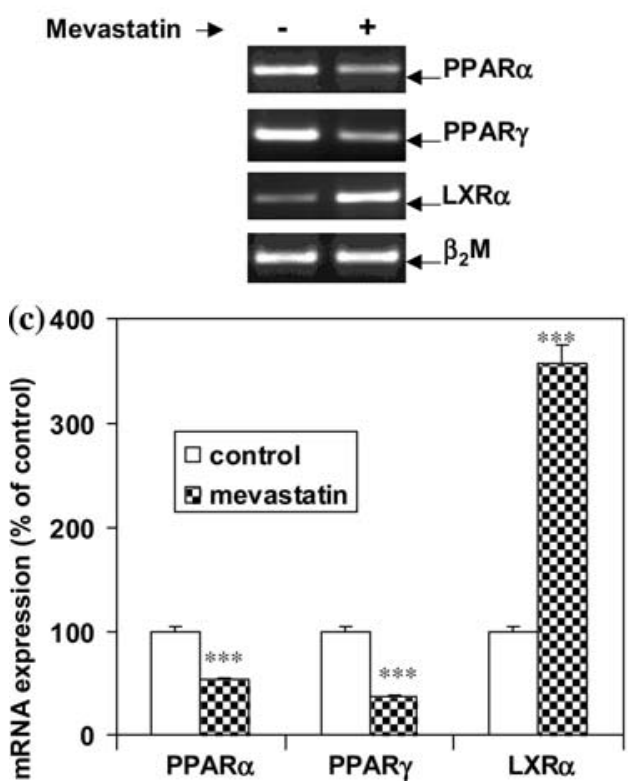
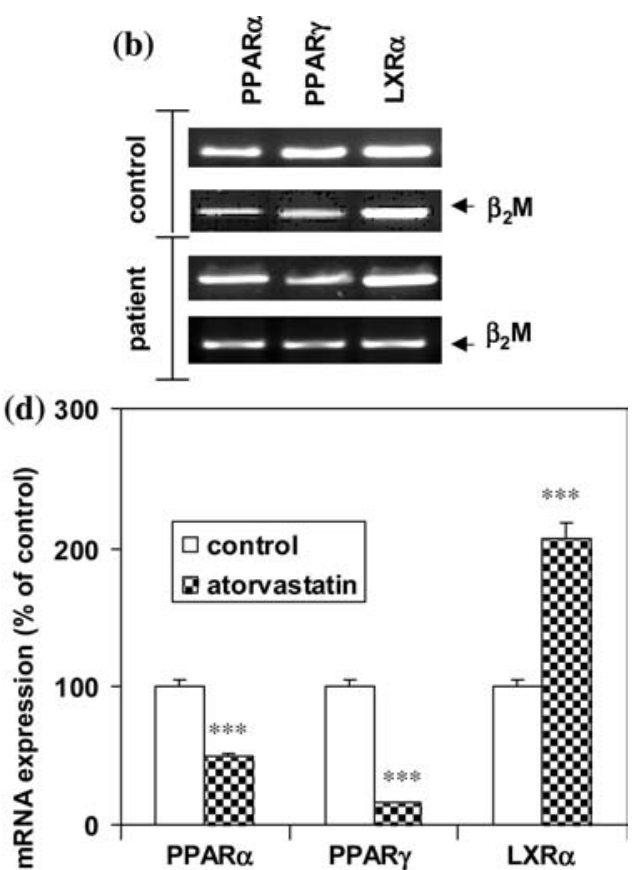

Figure 5. Representative transcriptional expression of genes coding for PPAR $\alpha, \operatorname{PPAR} \gamma, \mathrm{LXR} \alpha$ and $\beta_{2} \mathrm{M}$ in blood mononuclear cells derived from: (a) normal subjects exposed to growth medium enriched without or with mevastatin (30 $\mu \mathrm{M})$. (b) CHD patients who were receiving $20 \mathrm{mg}$ of atorvastatin orally daily. \% fold induction of genes coding for PPAR $\alpha$, PPAR $\gamma$ and LXR $\alpha$ deduced from: (c) densitometric scanning of the amplicons (Figure 5a) coupled with Scion Image analysis. (d) densitometric scanning of the amplicons (Figure 5b) coupled with Scion Image analysis. Each bar represents mean \pm SEM of the experiments performed in triplicate and $* * *$ indicates values significantly different $(p<0.001)$.

\section{Discussion}

Global acceptance of the fact that interplay of lipid peroxidation and inflammation is responsible for the initial development of atherosclerotic lesions, has prompted various investigators to explore various genes involved in these fundamental processes. The genes which have attracted tremendous attraction are PPARs $(\alpha, \gamma), \operatorname{LXR} \alpha$ and $\mathrm{NF}-\kappa \mathrm{B}$ [22] belonging to the nuclear receptor cum transcription factor family, have the unique distinction in that these genes not only control the expression of $\mathrm{LXR} \alpha, \mathrm{CD} 36$ and $\mathrm{NF}-\kappa \mathrm{B}$ but also other effector genes which play key role in the cooperativity that exists between oxidative and inflammatory process [23]. It is in this context that the results reported here assume tremendous importance in the sense that out of all the genes studied within blood mononuclear cells derived from subjects belonging to Groups I-IV, LXR $\alpha$ mRNA expression not only showed negative correlation with the severity of coronary atherosclerosis but also with the serum total cholesterol level (Figures 2 and 4). Studies directed to understand the intergene correlations within blood mononuclear cells from subjects belonging to Groups I and III, revealed significant positive correlations of PPAR $\alpha$ gene with respect to genes coding for LXR $\alpha$ and LDLR. Similar pattern of correlations was observed between $\operatorname{PPAR} \gamma$ and LXR $\alpha$, and PPAR $\gamma$ and LDLR (Figure 3a) in subjects belonging to Groups I and III. Further intergene expression profile correlations within blood mononuclear cells from subjects of Groups II and IV also revealed significant positive correlation between genes coding for PPAR $\gamma$ and $\mathrm{LXR} \alpha$ and this phenomenon was accompanied by a significant negative correlation between genes coding for LDLR and PPAR $\gamma$ (Figure $3 b$ ). These observations are in conformity with the transcriptional regulatory pathways that exist between the genes coding for PPARs $(\alpha, \gamma)$ and LXR $\alpha$ [24]. However, the observed positive correlations between PPARs $(\alpha, \gamma)$ and LDLR is in contrary to the transcriptional regulatory pathways that exist between these genes. PPARs $(\alpha, \gamma)$ gene products 
have been shown to interact with the transcription factor $\mathrm{Sp} 1$ and this interaction does not allow $\mathrm{Sp} 1$ protein to be translocated to the nucleus - a process required for the activation of LDLR gene promoter [13, 25, 26]. These results conspicuously reveal that subjects afflicted with CHD having either normocholesterolemic or hypercholesterolemic profile possess deregulated crosstalk regulation of genes coding for LDLR and PPARs $(\alpha, \gamma)$ within their blood mononuclear cells. These novel genomic expressional aberrations might be of importance in not only understanding the genesis of atherosclerotic CHD but also the paradoxical relationship of serum cholesterol profile with initiation of atherosclerotic process in coronary arteries.

These results were further strengthened by the fact that statins had the inherent capacity to upregulate genes coding for LXR $\alpha$ (Figure 5). However we also observed significant higher blood cellular LXR $\alpha$ mRNA expression (Figure 1b) in subjects belonging to diseased groups I and III as compared to subjects belonging to control groups II and IV. The selective and conspicuous expression of LXR $\alpha$ gene (Figure 1b) in CHD patients (with and without hypercholesterolemia) underlines the importance of this gene in the pathogenesis of CHD. This result raises two questions: First, does the observed overexpression of LXR $\alpha$ gene in mononuclear cells reflect genetic aberration as a consequence of this disease? Second, does the observed LXR $\alpha$ gene overexpression reflect Nature's protection against the development of CHD? Consequently, in order to address these questions it becomes imperative to understand the functional importance of this gene.

$\mathrm{LXR} \alpha$ also is an intracellular sterol sensor that not only regulates expression of genes controlling cholesterol absorption, excretion, catabolism and cellular efflux in target organs [27] but also represses genes involved in inflammation [28]. Our findings are in conformity with the observations: (a) statin downregulates genomic expression of PPAR $\gamma$ and CD36 [29], and upregulates LXR $\alpha$ gene expression (Figure 5b)) synthetic LXR $\alpha$ ligands have been shown to inhibit development of atherosclerosis in mice [30]. Based on abovementioned observations, it is not unlikely that $\mathrm{LXR} \alpha$ gene may be a protective mechanism against the development of coronary atherosclerosis. This view is further strengthened by the data, reported here, that shows negative correlation with the severity of CHD (Figure 4e). Hence from the findings reported here as well as in the literature, the blood cellular LXR $\alpha$ genomic profile may prove to be a critical therapeutic/prognostic marker for severity of CHD.

\section{Acknowledgements}

This study forms part of a thesis to be submitted to Post Graduate Institute of Medical Education and Research, Chandigarh, India for the award of degree of Doctor of Philosophy.

\section{References}

1. Ross R., The pathogenesis of atherosclerosis: a perspective for the 1990s. Nature 362: 801-809, 1993.

2. Kutuk O. and Basaga H., Inflammation meets oxidation: $\mathrm{NF}-\kappa \mathrm{B}$ as a mediator of initial lesion development in atherosclerosis. Trends. Mol. Med. 9: 549-557, 2003.

3. Lazar M.A., Progress in cardiovascular biology: PPARs for the course. Nat. Med. 7: 23-24, 2001.

4. Devchand P.R., Keller H., Peter J.M., Vazquez M., Gonzalez F.J. and Wahli W., The PPAR $\alpha$-leukotriene B4 pathway to inflammation control. Nature 384: 39-43, 1996.

5. Ricote M., Huang J.T., Welch J.S. and Glass C.K., The peroxisome proliferator- activated receptor-gamma as a regulator of monocyte/macrophage function. J. Leukoc. Biol. 66: 733-739, 1999.

6. Tontonoz P., Nagy L., Alvarez J., Thomazy V. and Evans R.M., PPAR $\gamma$ promotes monocyte/macrophage differentiation and uptake of oxidized LDL. Cell 93: 241-252, 1998.

7. Chinetti G., Gbaguidu F.G., Griglio S., Mallat Z., Antonucci M., Poulain P., Chapman J., Fruchart J.C., Tedgui A., Najib- Fruchart J. and Staels B., CLA-1/SR-BI is expressed in atherosclerotic lesion macrophages and regulated by activators of peroxisome proliferator-activated receptors. Circulation 101: 2411-2417, 2000.

8. Kersten S., Desvergne B. and Walter W., Roles of PPARs in health and disease. Nature 405: 421-424, 2000.

9. Kaul D., Molecular link between cholesterol, cytokines and atherosclerosis. Mol. Cell. Biochem. 219: 65-71, 2001.

10. Repa J.J., Liong G. and Ou J., Regulation of mouse sterol regulatory element binding protein-Ic (SREBP-Ic) gene by oxysterol receptors LXR $\alpha$ and LXR $\beta$. Genes Develop. 14: 2819-2830, 2000.

11. Wilson T.M., Brown P.J., Sternbach D.D. and Henke B.R., The PPARs: from orphan receptors to drug delivery. J. Med. Chem. 43: 527-551, 2000.

12. Repa J.J. and Mangelsdorf D.J., The liver X receptor gene team: Potential new players in atherosclerosis. Nat. Med. 8: 1243-1248, 2002.

13. Sugawara A., Urono A., Kudo M., Ikeda Y., Sato K., Taniyama Y., Ito S. and Takeuchi K., Transcriptional suppression of thromboxane receptor gene by peroxisome proliferator-activated receptor-gamma via an interaction 
with $\mathrm{Sp} 1$ in vascular smooth muscle cells. J. Biol. Chem. 277: 9676-9683, 2002

14. Nagy L., Tontonoz P., Alvarez J.G., Chen H. and Evans R.M., Oxidized LDL regulates macrophage gene expression through ligand activation of PPAR $\gamma$. Cell 93: 229-240, 1998.

15. Executive summary of the third report of the National Cholesterol Education Program (NCEP), Expert panel on Detection, Evaluation and Treatment of High Blood Cholesterol in Adults (Adults Treatment Panel III). JAMA 285: 2486-97, 2001.

16. Gensini G.G., A more meaningful scoring system for determining the severity of coronary heart disease. Am. J. Cardiol. 51: 606-607, 1983.

17. Boyum A., Ficoll-Hypaque method for separating mononuclear cells and granulocytes from human blood. Scand. J. Clin. Lab. Invest. 77(Suppl) 57-62, 1968

18. Chomczynski P. and Sacchi N., Single step method of RNA isolation by acid guanidium thiocyanate phenol chloroform extraction. Anal. Biochem. 162: 156-159, 1987.

19. Auboeuf D., Reiusset J., Fajas L., Vallier P., Frering V., Riou J.P., Staels B., Auwerx J., Laville M. and Vidal H., Tissue distribution and quantification of the expression of mRNAs of peroxisome proliferator-activated receptors and liver X receptor $\alpha$ in humans. Diabetes 46: 13191327, 1997.

20. Draude G. and Lorenz R.L., TGF- $\beta_{1}$ downregulates CD36 and scavenger receptor A but upregulates LOX-1 in human macrophages. Am. J. Physiol. Heart. Circ. Physiol. 278: H1042-H1048, 2000.

21. Xu D., Gruber A., Peterson C. and Pisa P., Telomerase activity and the expression of telomerase components in acute myelogenous leukemia. Br. J. Haematol. 102: 13671375, 1998.

22. Chawla A., Barak Y., Nagy L., Liao D., Tontonoz P. and Evans R.M., PPAR $\gamma$ dependent and independent effects on macrophage gene expression in lipid metabolism and inflammation. Nat. Med. 7: 48-52, 2001.

23. Duval C., Chinetti G., Trottein F., Fruchant J.C. and Staels B., The role of PPARs in atherosclerosis. Trends. Mol. Med. 8: 422-430, 2002.

24. Chinetti G., Lestavel S., Bocher V., Remaley A.T., Neve B., Torra I.P., Teissier E., Minnich A., Jaye M., Duverger N., Brewer H.B., Fruchart J.C., Clavey V. and Staels B., PPAR $\alpha$ and PPAR $\gamma$ activators induce cholesterol removal from human macrophage foam cells through stimulation of the ABCA1 pathway. Nat. Med. 7: 53-58, 2001.

25. Meissner M., Stein M., Urbich C., Reisinger K., Suske G., Staels B., Kaufmann R. and Gille J., PPAR $\alpha$ activators inhibit vascular endothelial growth factor receptor-2 expression by repressing Sp1-dependent DNA binding and transactivation. Circ. Res. 94: 324-332, 2004.

26. Sanchez H.B., Yieh L. and Osborne T.F., Cooperation by sterol regulatory element-binding protein and $\mathrm{Sp} 1$ in sterol regulation of low density lipoprotein receptor gene. J. Biol. Chem. 270: 1161-1169, 1995.

27. Jaye M., LXR agonists for the treatment of atherosclerosis. Curr. Opin. Investig. Drugs. 9: 1053-1058, 2003.

28. Tontonoz P. and Mangelsdorf D.J., Liver X receptor signaling pathways in cardiovascular disease. Mol. Endocrinol. 17: 985-993, 2003.

29. Han J., Zhou X., Yokohoma T., Hajjar D.P., Goto A.M. and Nicholson D.V.M., Pivastatin downregulates expression of the macrophage type B scavenger receptor, CD36. Circulation 109: 790-796, 2004.

30. Joseph S.B., McKilligin E., Pei L., Collins A.R., Laffitte B.A., Chen M., Noh G., Goodman J., Hagger G.N., Tran J., Tippin T.K., Wang X., Lusis A.J., Hsueh W.A., Law R.E., Collins J.L., Willson T.M. and Tontonoz P., Synthetic LXR ligand inhibits the development of atherosclerosis in mice. Proc. Natl. Acad. Sci. USA 11: 7604 7609, 2002. 